\title{
Murine Models of Renal Disease: Possibilities and Problems in Studies Using Mutant Mice
}

\author{
Hans-Joachim Anders Detlef Schlöndorff \\ Medizinische Poliklinik der Ludwig-Maximilians-Universität, München, Deutschland
}

\section{Key Words}

Renal disease - Glomerulonephritis •

Glomerulosclerosis · Interstitial nephritis · Backcrossing •

Renovascular hypertension - Transgenic mice

\begin{abstract}
The elucidation of the pathogenesis of human renal disease at the molecular level has been facilitated by the growing field of gene targeting and the development of mouse strains with single-gene deletions - the 'knockout' mice. Experimental nephrology, therefore, requires well-characterized and reliable models of human renal disease that can be induced reproducibly in mice. Today surgical procedures for the induction of renal ischemia, chronic renal failure, and ureter obstruction are feasible in mice. Models of mesangioproliferative or crescentic glomerulonephritis, glomerulosclerosis, and tubulointerstitial disease are readily available; however, these depend heavily on the mouse genetic background. Attention to the genetic background and appropriate backcrossing are, therefore, of great importance in the design and interpretation of experimental studies, especially in transgenic mice. Simple murine models displaying the clinical features of other human renal diseases such as IgA nephropathy, membranous glomerulonephritis, and renal vasculitis are still lacking. Mouse strains that spontaneously develop distinct renal pathologies similar to
\end{abstract}

\begin{tabular}{ll}
\hline KARGER & ( 2000 S. Karger AG, Basel \\
Fax +4161306 1234 & \\
$\begin{array}{l}\text { E-Mail karger@karger.ch } \\
\text { www.karger.com }\end{array}$ & $\begin{array}{l}\text { Accessible online at: } \\
\text { www.karger.com/journals/exn }\end{array}$
\end{tabular}

lupus nephritis and focal-segmental glomerulosclerosis can be intercrossed with transgenic mice to study the impact of single-gene deletions on the renal phenotype. The present review provides a survey about currently available spontaneous and inducible murine models of renal disease with special attention to problems and future perspectives for their use in transgenic animals.

Copyright $(2000$ S. Karger AG, Basel

\section{Introduction}

Most of the present knowledge on renal physiology and pathophysiology is based on experimental work with laboratory animals. Important therapeutic concepts in nephrology were developed in animal models of renal disease. While rats have extensively been used for measuring renal physiologic processes, by, e.g., micropuncture and clearance studies, mice are usually preferred for immunological studies in general [1]. Because of their small size, mice are not as convenient as rats for surgical and micropuncture studies. On the other hand, the availability of many genetically defined strains and mouse-specific immunological reagents renders mice highly suitable for studies on cellular and humoral immunology of renal diseases. Inbred strains such as nude mice or severe combined immunodeficient mice are available to study the functional relevance of certain components of the immune

Dr. H.-J. Anders

Medizinische Poliklinik der Ludwig-Maximilians-Universität

Pettenkoferstrasse 8a, D-80336 München (Germany)

Tel. +498951603565, Fax +498951603420

E-Mail hjanders@clinbio.med.uni-muenchen.de 
system in experimental renal disease [2]. Compared to rats, there are many more mouse strains available with spontaneously occurring disease models, such as lupus nephritis, polycystic kidney disease, hypertension, interstitial disease, or diabetes [3-5]. Furthermore, the recent introduction of targeted gene disruption in embryonic stem cells by homologous recombination allows the development of mice with specific homozygous gene deletions, the knockout (-/-) mice [6]. By this technology, the functional role of distinct genes in the pathophysiology of disease can be studied [7]. Although most knockout mice have a normal phenotype, certain gene deletions can be lethal, depending on the function of the particular gene during embryonal development $[8,9]$. To study the relevance of such molecules in the pathophysiology of disease, the insertion of substrate-responsive promoters and cell type specific promoters allows the temporal control, i.e., switch on or switch off of gene expression, known as 'conditional gene targeting' or even cell type specific gene targeting [10]. The present and future technologies for generating transgenic mice offer great possibilities for studies on single or even multiple gene functions in distinct renal diseases. In order to exploit the transgene technology, reliable murine models of human renal disease are of particular importance [11].

\section{Experimental Disease in Transgenic Animals: Problems and Future Perspectives}

Understanding the molecular mechanisms of human renal diseases by identifying key genes may help to establish gene-targeted therapy concepts as more specific therapeutic strategies in nephrology [12]. The development of homozygous gene-deleted mutant mice offers great advantages for the functional study of single genes in the pathophysiology of disease processes [13]. Thus structural changes of chronic diseases can be elicited by overexpressing or eliminating genes. However, the phenotype of many disease models is rather strain specific and depends on the genetically determined immune response after a certain stimulus. Inbred laboratory mouse strains such as $\mathrm{C} 57 \mathrm{BL} / 6$ or Balb/c are, therefore, required. Unfortunately, the generation of transgenic mice requires the embryonic stem (ES) cells of the 129 mouse strain with an undefined genetic background. The problem of an undefined genetic background in transgenes also includes the lack of adequate controls. Because of marked polymorphism in the genetic background of many laboratory mouse strains, it cannot be concluded that the null muta- tion is the only cause for a phenotypical change [14]. This problem is widely underappreciated, since in early backcross generations even hybrid littermate controls are genetically different at the targeted gene locus and other gene loci. Due to technical reasons, gene targeting is usually carried out in the 129 strain ES cells, an outbread mouse strain. ES cell transfer into blastocystes of another mouse strain results in chimeras, of which homozygous individuals are further crossed with, e.g., C57BL/6 mice, resulting in a mixed 129/C57 genotype. According to Mendel's law, crossing of two $+/-$ mutants for the specific gene generates $\mathrm{F} 2$ offspring of a $1 \times(+/+)-2 \times(+/-)-$ $1 \times(-/-)$ genotype. Inbreeding of homozygous $-/-$ and $+/+$ F2 offspring results in two genetically different inbred lines, one $-/-$ and the other $+/+$, for the targeted gene. However, the genetic background is completely different due to inbreeding of two segregated genetically different strains. Therefore, using such a crossing regimen does not produce appropriate controls for null mutants. Instead, simultaneous backcrossing into two congenic strains, i.e., 129 strain of the ES cell and C57BL/6 of the blastocyte origin, is necessary. F1 hybrids of these different backcross strains have a well-defined 50:50 genotype [15]. However, alleles of genes that closely surround the targeted locus are derived from the ES cell origin and may remain together with the mutated gene because the probability of genetic recombination relies on the distance between the gene loci. This aspect may be important in backcrossing null mutants of, e.g., immunoglobulin, cytokine, or chemokine genes which appear in gene clusters.

Backcrossing or crossbreeding is also required for studies in particular strains with spontaneously occurring renal disease or when disease susceptibility is restricted to a specific strain. Starting from unrelated strains, a congenic line is statistically expected to be $99.9 \%$ congenic after ten generations of backcrossing, which may take as much as 2 years of breeding time. After the fifth backcross generation, the contribution of additional backcrossing is limited, so that the use of F5 congenic strain hybrids for initial experiments has been suggested [15]. Clearly, the large variations in, e.g., immunological responses between different mouse strains pose a major problem with the interpretation of experimental disease variations in transgenic mice when adequate backcrossing has not been performed. This problem cannot be underestimated [16]. Establishing robust pluripotent C57BL/6 ES cell lines would help to generate null mutants without genetic polymorphism, but unfortunately such ES cells are currently not available. Today the most promising perspective is the generation of transgenic animals with inducible ex- 
pression of targeted genes. Such conditional knockouts also avoid the problem of compensatory mechanisms of null mutants and can be cell or organ specific. The cre-lox system uses bacteriophage-derived Cre recombinase to catalyze site-specific recombination by crossing-over between two Cre recognition sequences (i.e., LoxP sites) [17]. DNA sequences introduced between two LoxP sites can be excised by Cre-related recombination. Controlling Cre expression by insertion of a hormone-responsive promoter construct allows temporal control of gene expression, known as 'conditional gene targeting' [10]. Generating such animals does not require wild-type controls, as the phenotype can be analyzed before and after the conditional gene targeting experiment as an internal control. In transgenes, insertion of a stop codon between the promoter sequence and the targeted cDNA Cre-related recombination of the stop codon may also allow temporal switching off of gene overexpression [17]. Furthermore, recently tissue- or cell-specific promoter constructs have been used to generate conditional transgenic mice with a tissue-specific gene expression [18-20]. This may further overcome the problem of distinguishing between systemic versus local action of proteins, which is impossible by conventional gene targeting. For example, inverse glucokinase expression under the control of an intrinsic albumin or insulin promoter resulted in severe postnatal diabetes only in mice with pancreatic beta cell but not hepatocytespecific gene expression [21]. The impact of temporal and cell-specific control of gene expression on studies of renal physiology and disease has been reviewed recently [22].

As the genetic background is of such importance for transgenic studies, reproducible models of renal disease with a well-defined genetic background are essential. In the following, we, therefore, provide a survey of spontaneous or inducible models of experimental renal disease in mice. Procedures, susceptible mouse strains, and recent experiences in studies using mutant mice are summarized.

\section{Glomerulonephritis}

\section{Immune Complex Glomerulonephritis due to \\ Exogenous Antigens}

Human immune complex dependent glomerulopathies include lupus nephritis, IgA nephropathy, postinfectious and poststreptococcal glomerulonephritis, endocarditis, shunt infection associated nephritis, and glomerulonephritis caused by other unknown antigens. The classic example of experimental glomerulonephritis caused by immune complexes is serum sickness, resulting from an immune response against administered foreign antigens. Repeated injections of the antigen maintain a slight circulating antigen excess, causing immune complex deposition. However, since the immune response depends on size, charge, and antigenicity of the antigen, only few heterologous proteins have been shown to reliably cause progressive proliferative glomerulonephritis in susceptible mouse strains (table 1) [23-27].

Presensitization with antigen in adjuvant, as used by most protocols, is not required for the apoferritin-induced glomerulonephritis model [28]. The model is characterized by a mesangioproliferative and necrotizing glomerulonephritis with leukocyte infiltration, tuft thrombosis, and moderate proteinuria within 10-14 days and can progress to glomerulosclerosis [29]. Interstrain variations of apoferritin susceptibility are not related to the major histocompatibility complex, but depend on the production of high-avidity antibodies [30-32]. The susceptibility of $\mathrm{Balb} / \mathrm{c}$ but not of $\mathrm{C} 57 \mathrm{BL} / 6$ mice and the relation to antibody production indicates that the apoferritin model depends on a Th-2-type immune response. Using apoferritin-induced glomerulonephritis in C3-, C4-, and C5deficient mice, it was demonstrated that $\mathrm{C} 3$ and $\mathrm{C} 5$ are critical mediators of immune complex glomerulonephritis in vivo and that $\mathrm{C} 4$-deficient mice develop nephritis by activating $\mathrm{C} 3$ via the alternative pathway irrespective of glomerular IgG deposition [33, 34]. Apoferritin-induced glomerulonephritis is, therefore, a reliable model of mesangial proliferative immune complex glomerulonephritis in transgenes backcrossed into the Balb/c strain.

IgA nephropathy is the most common human glomerulonephritis, and much effort has been put into establishing an animal model with mesangial IgA deposits, hematuria, and proliferative glomerular lesions, unfortunately with only limited success to date [35, 36]. In mice, mesangial IgA deposits have been induced by different oral antigens such as gliadin, ovalbumin, lactalbumin, dextran, or ferritin or by experimental liver disease [3743]. These studies have focused on IgA immune complex deposition, but proliferative glomerulonephritis has not been observed. Montinaro et al. [44] have established a passive model of IgA nephropathy with hematuria, proteinuria, and severe diffuse mesangioproliferative glomerulonephritis by sequential administration of murine myeloma derived IgA antiphosphorylcholine antibodies and pneumococcal $\mathrm{C}$ polysaccharide antigen. However, due to the complicated immune complex preparation procedures, this model has not been used by other groups. Therefore, today there is no accepted and simple model of 
Table 1. Models of GN in mice

\begin{tabular}{|c|c|c|c|c|}
\hline Technique & Susceptible strains & Histopathology & $\begin{array}{l}\text { Protein- } \\
\text { uria }\end{array}$ & $\begin{array}{l}\text { Refe- } \\
\text { rences }\end{array}$ \\
\hline \multicolumn{5}{|l|}{ Immune complex $G N$} \\
\hline Horse spleen apoferritin $4 \mathrm{mg}$ i.p. daily for 2 weeks & B10, D2, NZB, Balb/c, Swiss & $\begin{array}{l}\text { mesangioproliferative } \\
\text { necrotizing GN }\end{array}$ & ++ & 29 \\
\hline $\begin{array}{l}\text { BSA } 0.5 \mathrm{mg} \text { s.c. on weeks } 0,2 \text {, and } 4 ; \\
\text { from week } 60.1-0.5 \mathrm{mg} \text { i.p. daily }\end{array}$ & $\mathrm{C} 3 \mathrm{H} / \mathrm{NB}$ & $\begin{array}{l}\text { mesangioproliferative or } \\
\text { crescentic GN }\end{array}$ & + & 27 \\
\hline \multicolumn{5}{|l|}{ IgA GN } \\
\hline IgA anti-PC and PnC i.v. & C57/BL6 & mesangioproliferative GN & ++ & 44 \\
\hline \multicolumn{5}{|l|}{ Mesangioproliferative GN } \\
\hline Habu venom, $4 \mathrm{mg} / \mathrm{kg}$ & $\mathrm{C} 57 \mathrm{BL} / 6 \mathrm{~N}, \mathrm{BALB} / \mathrm{c}, \mathrm{GRS} / \mathrm{A}$ & $\begin{array}{l}\text { mesangioproliferative } \mathrm{GN} \text {, } \\
\text { capillary cysts }\end{array}$ & ++ & 67 \\
\hline \multicolumn{5}{|l|}{ Lupus nephritis } \\
\hline Spontaneous polyclonality and lupuslike disease & $(\mathrm{NZBxNZW)F1,} \mathrm{MRL-lpr/lpr}$ & $\begin{array}{l}\text { all WHO classes of } \\
\text { lupus nephritis }\end{array}$ & +++ & 69 \\
\hline \multicolumn{5}{|l|}{ Anti-GBM GN } \\
\hline Sheep antimouse GBM globulin i.v. & C57/BL6, Balb/c & crescentic GN & +++ & 48 \\
\hline $\begin{array}{l}\text { Sheep IgG s.c.; after } 10 \text { days sheep antimouse } \\
\text { GBM globulin } 10 \mathrm{mg} \text { i.v. }\end{array}$ & C57/BL6, Balb/c & crescentic GN & +++ & 50 \\
\hline
\end{tabular}

$\mathrm{GN}=$ Glomerulonephritis; BSA = bovine serum albumin; anti-PC $=$ antiphosphorylcholine antibodies; PnC $=$ pneumococcal $\mathrm{C}$ polysaccharide; GBM = glomerular basement membrane.

IgA nephropathy available. This may relate to the recent observation that specific alterations in the glycosylation of IgA contribute to the development of human IgA nephritis [45]. So far, these findings have not been taken into consideration when trying to establish murine models of IgA nephropathy.

\section{Nephrotoxic Serum Nephritis}

Nephrotoxic serum (NTS) nephritis is a commonly used model for antiglomerular basement membrane nephritis (anti-GBM) or in situ immune complex glomerulonephritis. The passive model using a single intravenous injection of heterologous antiserum is currently preferred in studies focusing on the immunology of glomerulonephritis [1, 46, 47]. NTS is classically raised in sheep or rabbits against crude preparations of glomeruli or GBM and contains polyclonal antibodies against multiple GBM, tubular basement memebrane (TBM), and endothelial, mesangial, and epithelial cell wall antigens [48]. The NTS nephritis model is characterized by two different phases resembling different diseases. An early heterologous phase due to linear anti-GBM antibody deposition in the glomerulus that resembles anti-GBM disease; a subsequent autologous immune response against the planted antibodies results in an in situ immune complex formation, i.e., that resembles, e.g., postinfectious glomerulonephritis [48]. The autologous phase of NTS nephritis can progress to crescentic glomerulonephritis [49]. Preimmunization with rabbit IgG in incomplete Freund's adjuvant 3-5 days prior to administration of a subnephritic dose of rabbit antimouse GBM antiserum results in an augmented autologous phase with nephrotic-range proteinuria and acceleration of proliferative glomerular lesions within 2-4 days [50]. Histologically a glomerular infiltrate and a mixed periglomerular infiltrate are found. The cell type of the glomerular infiltrate varies among different inbred mouse strains. Th1-prone C57BL/6 mice develop glomerular accumulation of CD4-positive $\mathrm{T}$ cells and macrophages, whereas neutrophils predominate in Th2prone Balb/c mice $[51,52]$. Inducing NTS nephritis in interleukin 4 deficient mice supported the concept of crescent formation as a delayed-type hypersensitivity (Th1) response, since interleukin 4 deficiency (one of the essential mediators of Th2 responses) enhanced crescentic glomerular injury, [53, 54]. NTS nephritis has also been used in mice deficient in various mediators of the endothelium-leukocyte interaction. Glomerular leukocyte infiltration was decreased in mice deficient in intercellu- 
lar adhesion molecule $1, \mathrm{C} 3$, and $\mathrm{C} 4$, indicating the key role of these factors during development of the leukocytic infiltrate in this model $[55,56]$. However, in mice deficient in monocyte chemoattractant chemokine 1, tubular injury but not glomerular damage was reduced, which suggested a differential regulation of inflammation in kidney compartments [57]. Glomerular damage remained also unchanged in NOS-2 and mu chain deficient mice, illustrating that these factors do not play an essential role in this model of glomerulonephritis [58, 59]. It should be pointed out, however, that some of these studies were performed in knockout mice with insufficient backcrossing, so that conclusions may not yet be firm.

Due to the progression of NTS nephritis to crescentic glomerulonephritis during the autologous phase, this model is useful for studies of renal fibrogenesis. The role of various factors during renal fibrogenesis could be demonstrated by a diminished crescent formation and renal fibrosis after injection of NTS in mice deficient in either tumor necrosis factor alpha, angiotensin II, major histocompatibility complex class II, CD4, or CD8 [60-63]. These studies showed that renal fibrosis secondary to glomerular inflammation depends on several paracrinesecreted peptides and on cell surface receptors on intrinsic renal cells or infiltrating leukocytes.

In summary, the NTS model represents a well-established model of anti-GBM disease during the heterologous phase and of crescentic immune complex glomerulonephritis during the autologous phase. The variant course in Th1- and Th2-prone mouse strains allows studies of the heterologous phase in the more humoral or cellular immune responses of the different genetic backgrounds. However, careful backcrossing of transgenes into the specific mouse strains is essential. Reliable development of crescentic glomerulonephritis during the autologous phase of NTS nephritis makes this model useful for studies of renal fibrogenesis and progressive renal failure. However, due to the various antisera used, the two phases of the model, and important strain differences, results of different studies using NTS nephritis cannot readily be compared to each other.

Mesangioproliferative glomerulonephritis can be induced in rats and mice by a single intravenous injection of $4 \mathrm{mg} / \mathrm{kg}$ of Habu snake venom (Trimeresurus flavoviridis). The model is similar to the anti-Thy-1 nephritis in rats [64]. Within 3 days mesangiolysis is followed by glomerular cyst formation, and focal mesangioproliferative lesions can be observed [65]. Histopathological abnormalities include focal mesangial hypercellularity and nodular mesangial lesions [64]. This model is particularly useful to study mesangial proliferation independent of leukocyte infiltration. At least in rats the initial phase of Habu snake venom toxicity relies on platelet-dependent endothelial damage which can be suppressed by antiplatelet agents, whereas in mice the resolution of the proliferative lesions depends on the cell-intercellular matrix interaction [66, 67].

\section{Lupus Nephritis}

Mouse strains with spontaneous polyclonal B cell activation, such as Fas-deficient MRL-lpr/lpr mice or New Zealand black/white F1 hybrids, develop renal changes comparable to those found in human lupus nephritis [23, 68-70]. Lupus nephritis is considered to have a multigenetic susceptibility. Therefore, susceptibility genes in specific mouse strains favor the development of a phenotype which develops lupus nephritis after an unknown triggering event [71]. Murine systemic lupus erythematosus strains have, therefore, been used to study the polygenetic basis of the susceptibility to lupus nephritis [72]. In systemic lupus erythematosus, circulating immune complexes deposit in the glomerular subendothelial space and in the mesangium, leading to glomerulonephritis. The development of glomerular lesions involves multiple adhesion molecules, cytokines, chemokines, lipid mediators, and Fc receptors [71]. Recently, crossbreeding Fc gamma receptor deficient mutants with NZB/NZW hybrids resulted in mutant mice which showed glomerular immune complexes and complement deposits, but did not develop severe nephritis [73, 74]. These studies have been interpreted to indicate a role for $\mathrm{IgG}$ receptors in the development of immune complex glomerulonephritis. Nephritis was also prevented in interferon gamma receptor deficient MRL mice [75]. Crossbreeding of mice deficient in intercellular adhesion molecule 1 with MRL mice abrogated pulmonary inflammation, but not spontaneous glomerulonephritis [76]. These studies illustrate the strategy of combining transgenic mice with mutants carrying spontaneous renal disease. Attempts to induce systemic lupus erythematosus in mice without a specific genetic background failed to establish a model mimicking human lupus nephritis, again indicating the importance of genetic susceptibility.

\section{Glomerulosclerosis}

Glomerulosclerosis is part of the final stage of many immunologic and nonimmunologic glomerular disorders [77]. The current pathogenic concepts of diffuse glomeru- 
Table 2. Models of diabetic nephropathy and glomerulosclerosis in mice

\begin{tabular}{|c|c|c|c|}
\hline Technique & Susceptible strains & Histopathology & $\begin{array}{l}\text { Refe- } \\
\text { rences }\end{array}$ \\
\hline \multicolumn{4}{|l|}{ Diabetic nephropathy } \\
\hline $\begin{array}{l}\text { Uninephrectomy, streptozotocin i.p. } \\
\text { for } 5 \text { days } 1 \text { week later }\end{array}$ & CD-1, others? & $\begin{array}{l}\text { mesangial expansion, GBM thickening, } \\
\text { glomerulosclerosis }\end{array}$ & 96 \\
\hline Hyperinsulinemic diabetic mice & $\mathrm{db} / \mathrm{db}, \mathrm{KKay}, \mathrm{NZO}$ & GBM thickening, diffuse glomerulosclerosis & 100,101 \\
\hline Hypoinsulinemic diabetic mice & NOD & GBM thickening, diffuse glomerulosclerosis & 98 \\
\hline \multicolumn{4}{|l|}{ Glomerulosclerosis } \\
\hline $\begin{array}{c}4 \times \text { lymphocytes from } \mathrm{DBA} / 2 \text { mice in } \\
\text { 3- to 4-day intervals i.v., } 10 \text { weeks }\end{array}$ & $(\mathrm{C} 57 \mathrm{~B} 1 / 10 \times \mathrm{DBA} / 2) \mathrm{F} 1$ hybrids & diffuse glomerulosclerosis & 92 \\
\hline GH transgenic mice & MThGH transgene, NMRI & progressive glomerulosclerosis & 81 \\
\hline Oligosyndactyly (Os) mouse & Os/+ ROP & $50 \%$ nephron number, glomerulosclerosis & 88 \\
\hline Others & SV40Tag, Thy-1, Mpv17/Mpv17 & diffuse glomerulosclerosis & $85,86,87$ \\
\hline
\end{tabular}

$\mathrm{GH}=$ Growth hormone; $\mathrm{MThGH}=$ metallothionein I promoter human growth hormone; GBM = glomerular basement membrane .

losclerosis include genetic susceptibility, glomerular hypertrophy, podocyte damage, and glomerular hyperfiltration [78-80]. Commonly used mouse strains which spontaneously develop glomerulosclerosis are listed in table 2 .

A well-characterized murine model of spontaneous glomerulosclerosis is the growth hormone overexpressing transgenic mouse [81-84]. Mice develop growth hormone related glomerular hypertrophy with an increase of extracellular mesangial matrix, resulting in focal-segmental glomerulosclerosis between 7 and 9 weeks of age [84]. Progression to end-stage renal failure is characterized by increasing nephrotic-range proteinuria, diffuse glomerulosclerosis, tubular atrophy, and interstitial fibrosis. Other transgenic mouse strains that spontaneously develop glomerulosclerosis (if not kept in a germ-free environment) include Thy-1, SV40Tag, and Mpv17/Mpv17 transgenic mice [85-87]. The mechanisms and genes involved in this process are not known. These observations also illustrate the importance of keeping all transgenes and their controls in a specific pathogen free animal facility [85-87].

Another strain of mice with spontaneous development of glomerulosclerosis is the oligosyndactyly (Os) mouse [88]. Heterozygous animals of a ROP and a C57 background are born with a $50 \%$ reduction in the number of nephrons associated with an increased glomerular volume of the remaining nephrons [89]. The fact that an increase of the mesangial matrix and glomerulosclerosis did only occur in the ROP background argues for an inherited susceptibility to glomerulosclerosis [90].
Glomerulosclerosis may also occur late in the course of immune system mediated glomerulopathies [91, 92]. One group [29] has reported that $85 \%$ of their Balb/c mice developed diffuse glomerulosclerosis 4 months after an initial 2-week immunization with apoferritin, but this observation needs to be confirmed.

\section{Diabetic Nephropathy}

Diabetic nephropathy is the most common cause of glomerulosclerosis in humans [79]. Animal models of diabetes have used the beta cell toxin streptozotocin to reliably induce insulin-dependent diabetes mellitus in various rodents including mice (table 2) [93-95]. Uninephrectomy before induction of diabetes can shorten the interval until typical glomerular abnormalities occur [96]. Furthermore, several mouse strains that spontaneously develop diabetes mellitus have been established [97]. Amongst those the hypoinsulinemic nonobese diabetic mouse and hyperinsulinemic ob/ob and KKAy mice develop only minimal renal abnormalities [98-100]. The hyperinsulinemic diabetes mouse $(\mathrm{C} 57 \mathrm{BL} / 6 \mathrm{db} / \mathrm{db})$ develops progressive renal disease characterized by kidney enlargement, hyperfiltration, and progressive proteinuria during an early age [101]. Histopathological changes include diffuse and nodular thickening of the mesangial matrix, exudative lesions, and nodular thickening of he GBM [102, 103]. Similar lesions have also been found in polygenetically inherited diabetes of hyperinsulinemic New Zealand obese mice [104]. Crossing of nonobese diabetic mice 
Table 3. Models of tubulointerstitial nephritis in mice

\begin{tabular}{|c|c|c|c|c|}
\hline Technique & Susceptible strains & Histopathology & $\begin{array}{l}\text { Protein- } \\
\text { uria }\end{array}$ & $\begin{array}{l}\text { Refe- } \\
\text { rences }\end{array}$ \\
\hline Immunization with TBM in CFA s.c. & $\begin{array}{l}\text { SJL, CD1, A.CA, A.SW, } \\
\text { T.TL, Balb/c, NZB }\end{array}$ & tubular necrosis, lymphocyte infiltrate & + & 107 \\
\hline Unilateral ureter ligation & any & tubular atrophy, mixed infiltrate & + & 2 \\
\hline
\end{tabular}

$\mathrm{TBM}=$ Tubular basement membrane; CFA = complete Freund's adjuvant.

with $\beta_{2}$-microglobulin-deficient transgenes resulted in mice with a lack of CD8+ T cells [105]. As compared with diabetic controls, hybrids did not develop lymphocytic insulitis, which illustrates that CD8+ T cells play an essential role in the development of diabetes in nonobese diabetic mice. However, intercrossing with diabetic mice is difficult, especially in hypoinsulinemic mice. So far, the impact of single gene deletions on the renal pathology of diabetic mice has not been studied.

\section{Tubulointerstitial Nephritis and Obstructive Nephropathy}

Human tubulointerstitial nephritis with interstitial infiltrate, tubular atrophy, and interstitial fibrosis can be caused by drugs, toxins, infection, systemic immune disease, or obstructive nephropathy [106]. The mechanisms of immunological tubulointerstitial injury have been assigned to immune complex formation with planted nephritogenic antigens or with locally generated tubulointerstitial antigens and to cell-mediated immune mechanisms [107]. Combinations of these with toxic or ischemic injury may be common. Mouse strains that spontaneously develop interstitial nephritis and experimental approaches to interstitial nephropathy in mice are listed in table 3.

A natural mutant that spontaneously develops tubulointerstitial nephritis is the $k d k d$ mouse [108]. A mixed interstitial infiltrate followed by tubular atrophy and interstitial fibrosis develops after 8 weeks of life. The disease can be transferred by L3T4 lymph node T cells into cyclophosphamide-pretreated recipients of another inbred strain, which indicates the role of tubular antigenreactive $\mathrm{T}$ lymphocytes in the development of interstitial nephritis in kdkd mice [109]. However, crossbreeding of mice bearing transgenes with kdkd mice as a model of tubulointerstitial disease has not been performed.
Murine anti-TBM interstitial nephritis is induced by a single immunization with rabbit TBM [107]. Anti-TBM antibodies are detectable after 2 weeks, but lesions of the tubulointerstitial tissue do not occur before 9-16 weeks. The SJL mouse strain is the most susceptible, but A.CA, A.SW, T.TL, and NZB mice are also responding [110]. The susceptibility of mouse strains is related to the major histocompatibility complex class II H-2-phenotypic trait signalling $\mathrm{T}$ effector cells by proximal tubular cells [11, 112]. T lymphocyte transfer studies have also proven the relevance of $T$ cell autoimmunity in maintaining the chronic phase of this model [113]. As compared with NTS nephritis, anti-TBM nephritis is characterized by a long delay until typical lesions appear. Furthermore, the disease has not been characterized in inbred mouse strains. So far, anti-TBM interstitial nephritis has not been used in null mutants.

A murine model that predictably and uniformly induces tubulointerstitial damage independent of the genetic background is unilateral ureter obstruction (UUO) [114]. In adult mice the ureter is ligated supravesically by an anterior approach using the contralateral kidney as a control. 1-2 weeks after surgery a periglomerular and interstitial infiltrate composed predominantly of macrophages and T lymphocytes develops [2]. Persistent UUO results in progressive tubulointerstitial and periglomerular inflammation and fibrosis similar to what is found in human obstructive nephropathy [115]. Amelioration of interstitial collagen deposition after UUO was noted in angiotensinogen, transforming growth factor, and CCR2 deficient mice, indicating that many growth factors, cytokines, and chemokines are involved in the process of interstitial inflammation and renal fibrogenesis [116118]. Since angiotensin type 2 receptor null mutant mice and B7 transgenes developed an accelerated interstitial fibrosis after UUO, these molecules seem to be important regulators of fibrogenesis in obstructive nephropathy $[119,120]$. The ureter ligation model represents a repro- 
Table 4. Models of acute tubular necrosis in mice

\begin{tabular}{|c|c|c|c|c|}
\hline Technique & Susceptible strains & Histopathology & $\begin{array}{l}\text { Protein- } \\
\text { uria }\end{array}$ & $\begin{array}{l}\text { Refe- } \\
\text { rences }\end{array}$ \\
\hline \multicolumn{5}{|l|}{ Ischemia } \\
\hline $\begin{array}{l}\text { Renal artery clamping for } 30 \mathrm{~min} \text {, } \\
\text { reperfusion for } 1-3 \text { days }\end{array}$ & any & tubular necrosis & + & 122 \\
\hline \multicolumn{5}{|l|}{ Toxic tubular necrosis } \\
\hline Folic acid $200 \mathrm{mg} / \mathrm{kg}$ in $0.3 \mathrm{MNaHCO}_{3}$ i.p. & $\mathrm{CD} 1, \mathrm{C} 57 \mathrm{BL} / 6, \mathrm{Balb} / \mathrm{c}, \mathrm{DBA} / 2$ & tubular necrosis & ++ & 129 \\
\hline Mercury chloride $100 \mu \mathrm{mol} / \mathrm{kg}$ i.v. & $\mathrm{C} 3 \mathrm{H} / \mathrm{He}, 129 / \mathrm{Sv}, \mathrm{CBA} / \mathrm{Bom}$ & tubular necrosis & ++ & 141 \\
\hline Cadmium $0.2 \mathrm{mg} / \mathrm{kg}$ i.v. or i.p. & $\mathrm{C} 3 \mathrm{H} / \mathrm{HeJ}, \mathrm{CBA} / \mathrm{CA}, \mathrm{C} 57 / \mathrm{BL} 10, \mathrm{DBA} / 2 \mathrm{~J}$ & tubular necrosis & ++ & 137 \\
\hline King brown snake myotoxin $4.5 \mathrm{mg} / \mathrm{kg}$ i.m. & Swiss albino & $\begin{array}{l}\text { myolysis, myoglobin cast } \\
\text { nephropathy }\end{array}$ & ++ & 135 \\
\hline
\end{tabular}

ducible model of interstitial inflammation and fibrosis secondary to a nonimmune stimulus. The procedure is easily performed, and the time course for progression to renal fibrosis is short. Although the course may differ between various mouse strains, the model itself can be used in all strains. However, due to ureter ligation, proteinuria cannot be used as a functional parameter of renal damage in this model.

\section{Acute Renal Failure}

\section{Ischemic Acute Renal Failure}

Ischemia or hypoperfusion accounts for $50 \%$ of acute renal failures in humans [121]. The reperfusion following hypoperfusion has been implicated in the pathogenesis of tissue damage. Studies on the mechanisms of reperfusion injury in acute renal failure have used renal artery clamping for transient interruption of renal perfusion in mice (table 4) [122]. One kidney is exposed by flank incision, and the renal artery is clamped with a nontraumatic vascular clamp for 30 min using the contralateral kidney as a control [123]. Although immediate-early genes in renal tissue are already activated after $10 \mathrm{~min}$ of arterial occlusion, significant tubular injury related azotemia has only been found after $30 \mathrm{~min}$ of clamping and subsequent reperfusion during the next $24-72 \mathrm{~h}[124,125]$. Using this protocol, the relevance of adhesion molecules in the pathogenesis of ischemic nephropathy was studied. Intercellular adhesion molecule 1 deficient mice were protected from acute renal ischemic injury, whereas L-selectin-deficient mutants had an unchanged response as compared with wild-type controls [126-128]. However, interpretation of renal artery clamping data must consider the uncertainties of this model. Ischemia-related renal injury may vary from animal to animal due to technical problems such as surgery, blood loss, maintenance of body temperature during anesthesia, length of operation, and arterial hypotension during the postoperative period which is influenced by the anesthetics and analgesics used. As in humans, the surgical skill of the experimentator has considerable influence on the outcome even when a standardized 'ischemia' time is used.

\section{Toxic Tubular Necrosis}

Nephrotoxins that reliably induce acute tubular necrosis in mice include folic acid, cadmium, mercury, and king brown snake venom as listed in table 4. Depending on the dose administered, either a temporary decrease of renal function or lethal uremia occurs.

A single intraperitoneal injection of folic acid in sodium bicarbonate induces acute renal failure and compensatory hypertrophy between days 1 and 4 in mice of most strains $[129,130]$. Degree and reversibility of acute renal failure are related to the dose administered. Because of the good reproducibility of folic acid induced tubular necrosis, this model has been commonly used for studies of differential gene expression after acute renal injury [131, 132].

Trauma-related myoglobinuria is a common cause of acute tubular necrosis [133]. Ponraj and Gopalakrishnakone [134] have developed a murine model of myoglobin cast nephropathy by injecting $4.5 \mathrm{mg} / \mathrm{kg}$ of king brown snake venom (Pseudechis australis) which causes rhabdomyolysis (table 4). Experimental mice develop myoglobinuria $60 \mathrm{~min}$ after administration of the myotoxic venom. Myocyte necrosis and macrophage infiltration were observed as early as $30 \mathrm{~min}$, with the peak of infiltration 
Table 5. Models of chronic renal failure (remnant-kidney models) in mice

\begin{tabular}{llll}
\hline Technique & Mortality, \% & Characteristics & References \\
\hline $\begin{array}{l}\text { Electrocoagulation of the anterior surface of the } \\
\text { right kidney, left-sided nephrectomy after 2-3 weeks }\end{array}$ & $4-15$ & $\begin{array}{l}\text { growth retardation, anemia, azotemia, osteodystrophy, } \\
\text { polyuria, proteinuria }\end{array}$ & 146 \\
\hline $\begin{array}{l}\text { Diathermy of the anterior surface and ligation } \\
\text { of the upper and lower poles of the right kidney, } \\
\text { left-sided nephrectomy after 2 weeks }\end{array}$ & $20-50$ & $\begin{array}{l}\text { growth retardation, anemia, azotemia, osteodystrophy, } \\
\text { altered immunological status }\end{array}$ & 144, 145 \\
$\begin{array}{l}\text { Diathermy of the left kidney anterior surface, } \\
\text { right-sided nephrectomy after 1 week }\end{array}$ & 20 & growth retardation, azotemia \\
\hline
\end{tabular}

after $12-48 \mathrm{~h}$ [135]. Histopathological changes of the kidney include intratubular myoglobin casts and tubular necrosis. Thus snake venom related rhabdomyolysis provides an excellent murine model for acute myoglobinuric renal failure.

Acute exposure to inorganic cadmium causes hepatotoxicity, but no renal injury [136]. In contrast, during chronic exposure cadmium is bound to metallothionein by the liver, and this compound is filtered and accumulates in renal tubular cells where it induces nephrotoxicity [137]. In mice, a single injection of $0.2 \mathrm{mg} / \mathrm{kg}$ cadmium bound to metallothionein can produce nephrotoxicity similar to that seen with chronic cadmium exposure [138]. Acute tubular dysfunction is characterized by marked proteinuria from day 1 to 5 after cadmium-metallothionein injection and by increasing levels of aminoaciduria and glucosuria with a peak on day 6 [137].

Environmental exposure to mercury compounds is an important cause of heavy metal induced renal toxicity in humans $[139,140]$. In mice, injection of $100 \mu \mathrm{mol} / \mathrm{kg}$ methylmercury chloride produces acute proximal tubular necrosis after 2-3 days, followed by regeneration between days 3 and 7 [141]. Strain and sex differences of renal toxicity rely on the distribution of apical $\gamma$-glutamyltranspeptidase in the proximal tubule which catalyzes transport of the mercury-glutathione complex [142]. All models are reproducible and can be induced by a single intraperitoneal injection which makes them suitable for studies of toxic tubular necrosis.

\section{Chronic Renal Failure (Remnant-Kidney Models)}

End-stage renal disease in mice can be induced by surgical reduction of the renal mass. By progressive reduction of the renal mass, various degrees of renal failure with the typical clinical, hematological, and biochemical features of uremia can be induced [143-146] (table 5). Careful ablation of the renal mass in a two-time procedure improves perioperative mortality, as listed in table 5 [143]. For the evaluation of progressive deterioration of renal function, mice have to be monitored carefully. In mice the serum creatinine levels do not parallel the glomerular filtration rate because of low muscle mass and tubular creatinine secretion, but the blood urea nitrogen concentration can be used instead [147, 148]. However, due to the ablation of renal mass, the amount of renal tissue that can be obtained for histological studies or RNA preparation is limited. The remnant-kidney model has, therefore, been used to study the humoral changes in uremia. The impaired host defense mechanisms observed in this model have been used to study uremia-related immunosuppression [149]. Other similarities to human disease such as the reversibility of anemia by recombinant erythropoietin underline the suitability of this model for studies of end-stage renal failure [150].

\section{Concluding Remarks}

Reliable murine models resembling many human renal disorders have been established for chronic renal failure, immune complex glomerulonephritis, lupus nephritis, tubulointerstitial nephritis, obstructive nephropathy, and diabetic nephropathy. Murine models displaying the clinical features of human disease are still lacking for such important disorders as IgA nephropathy, membranous glomerulonephritis, and renal vasculitis. Experimental renal diseases in mice are important because of the expanding field of gene targeting, molecular nephrology, and gene therapy. Differences in the response to injury and the immune response in different genetic mouse strains repre- 
sent a major problem in interpreting results obtained with transgenic mice. Backcrossing into two congenic strains for at least five generations is neccessary to obtain hybrids where wild-type and knockout littermates can reliably be compared. For several inducible models of renal disease, transgenes must be backcrossed into distinct susceptible inbred strains. The development of conditional transgenic mice with tissue- or cell-specific gene expression or suppression will be of particular importance in the future study of molecular mechanisms of renal disease.

\section{References}

1 Salant DJ, Cybulsky AV: Experimental glomerulonephritis. Methods Enzymol 1988;162: 421-461.

2 Shapell SB, Gurpinar T, Lechago J, Suk WN, Truong LD: Chronic obstructive uropathy in severe combined immunodeficient (SCID) mice: Lymphocyte infiltration is not required for progressive tubulointerstitial injury. J Am Soc Nephrol 1998;9:1008-1017.

3 Robinson RR, Dennis VW: Spontaneously occurring animal models of human kidney diseases and altered renal function. Adv Nephrol Necker Hosp 1980;9:315-366.

4 Schieren G, Pey R, Bach J, Hafner M, Gretz N: Murine models of polycystic kidney disease. Nephrol Dial Transplant 1996;11(suppl 6);3845.

5 Velasquez MT, Kimmel PL, Michaelis OE 4th: Animal models of spontaneous diabetic kidney disease. FASEB J 1990;4:2850-2859.

6 Majzoub JA, Muglia LJ: Knockout mice. N Engl J Med 1996;34:904-907.

7 Wang T, Giebisch G: Tubule function in transgenic mice. Exp Nephrol 1998;6:447-453.

8 Raabe M, Flynn LM, Zlot CH, Wong JS, Veniant MM, Hamilton RL, Young SG: Knockout of the abetalipoproteinemia gene in mice: Reduced lipoprotein secretion in heterozygotes and embryonic lethality in homozygotes. Proc Natl Acad Sci USA 1998;95:8686-8691.

9 Farese RV Jr, Ruland SL, Flynn LM, Stokowski RP, Young SG: Knockout of the mouse apolipoprotein B gene results in embryonic lethality in homozygotes and protection against diet-induced hypercholesterolemia in heterozygotes. Proc Natl Acad Sci USA 1995;28:17741778.

10 Rajewsky K, Gu H, Kuhn R, Betz UA, Muller W, Roes J, Schwenk F: Conditional gene targeting. J Clin Invest 1996;98:600-603.

11 Ryffel B: Gene knockout mice as investigative tools in pathophysiology. Int $\mathrm{J}$ Exp Pathol 1996;77:125-141.

12 Kitamura M: Transfer of genetically engineered cells to the glomerulus. Exp Nephrol 1997;7:259-266.

13 Lakkis FG: Role of cytokines in tansplantation tolerance: Lessons learned from gene-knockout mice. J Am Soc Nephrol 1998;9:2361-2367.

14 Lathe R: Mice, gene targeting, and behaviour: More than just genetic background. Trends Neurosci 1996;19:183-186.

15 Banbury Conference on Genetic Background in Mice: Mutant mice and neuroscience: Recommendations concerning genetic background. Neuron 1997;19:755-759.
16 Gerlai R: Gene-targeting studies of mammalian behavior: Is it the mutation or the background genotype? Trends Neurosci 1996;19: 177-181.

17 Furth PA, St Onge L, Boger H, Gruss P, Gossen $\mathrm{M}$, Kistner A, Bujard $\mathrm{H}$, Henninghausen L: Temporal control of gene expression in transgenic mice by a tetracycline-responsive promoter. Proc Natl Acad Sci USA 1994;91:93029306.

18 Lakso M, Sauer B, Mosinger B Jr: Targeted oncogene activation by site-specific recombination in transgenic mice. Proc Natl Acad Sci USA 1992;89:6232-6236.

$19 \mathrm{Gu} \mathrm{H}$, Marth JD, Orban PC, Mossmann H, Rajewsky K: Deletion of a DNA polymerase beta gene segment in T cells using cell type-specific gene targeting. Science 1994;265:103106.

20 Schwenk F, Kuhn R, Angrand PO, Rajewsky $\mathrm{K}$, Stewart AF: Temporally and spatially regulated somatic mutagenesis in mice. Nucleic Acids Res 1998;26:1427-1432.

21 Postic C, Shiota M, Niswender KD, Jetton TL, Chen Y, Moates JM, Shelton KD, Lindner J, Cherrington AD, Magnuson MA: Dual roles for glucokinase in glucose homeostasis as determined by liver and pancreatic beta cell-specific gene knock-outs using Cre recombinase. J Biol Chem 1999;274:305-315.

22 Jaisser F, Beggah AT: Transgenic models in renal tubular physiology. Exp Nephrol 1998;6: 438-446.

23 Furness PN, Harris K: An evaluation of experimental models of glomerulonephritis. Int J Exp Pathol 1994;75:9-22.

24 Noble B, Brentjens JR: Experimental serum sickness. Methods Enzymol 1988;162:484901.

25 Furness PN: The formation and fate of glomerular immune complex deposits. J Pathol 1991; 164:195-202.

26 Germuth FG, Rodriguez E, Lorelle CA, Trump EI, Milano L, Wise O: Passive immune complex glomerulonephritis in mice: Models for various lesions found in human diseases. I. High avidity complexes and mesangiopathic glomerulonephritis. Lab Invest 1979;41:360 365 .

27 Noble B, Olson KA, Milgrom M, Albini B: Tissue deposition of immune complexes in mice receiving daily injections of bovine serum albumin. Clin Exp Immunol 1980;42:255-262.
28 Hagstrom GL, Bloom BM, Yum MN, Lavelle KJ, Luft FC: Ferritin- and apoferritin-induced immune complex glomerulonephritis in mice. Nephron 1979;24:127-133.

29 Iskandar SS, Gifford DR, Emancipator SN: Immune complex acute necrotizing glomerulonephritis with progression to diffuse glomerulosclerosis: A murine model. Lab Invest 1988; 59:772-779.

30 Iskandar SS, Jennette JC, Wilkman AS, Becker $\mathrm{RL}$ : Interstrain variations in nephritogenicity of heterologous protein in mice. Lab Invest 1982;46:344-351.

31 Iskandar SS, Jennette JC: Influence of antibody avidity on glomerular immune complex localization. Am J Pathol 1983;112:155-159.

32 Iskandar SS, Jennette JC: Interaction of antigen load and antibody response in determining heterologous protein nephritogenicity in inbred mice. Lab Invest 1983;48:726-734.

33 Falk RJ, Jennette JC: Immune complex induced glomerular lesions in C5 sufficient and deficient mice. Kidney Int 1986;30:678-686.

34 Quigg RJ, Lim A, Haas M, Alexander JJ, He C, Carroll MC: Immune complex glomerulonephritis in C4- and C3-deficient mice. Kidney Int 1998;53:320-330.

35 Galla JH: IgA nepropathy. Kidney Int 1995;47: 377-387.

36 Rifai A: Experimental models of IgA-associated nephritis. Kidney Int 1987;31:1-7.

37 Coppo R, Mazzucco G, Martina G, Rocatello D, Amore A, Novara R, Bargoni A, Piccoli G, Sena LM: Gluten-induced experimental IgA glomerulopathy. Lab Invest 1989;60:499-506.

38 Emancipator SN, Gallo GR, Lamm ME: Experimental IgA nephropathy induced by oral immunization. J Exp Med 1983;157:572-582.

39 Emancipator SN, Gallo GR, Razaboni R, Lamm ME: Experimental cholestasis promotes the deposition of glomerular IgA immune complexes. Am J Pathol 1983;113:19-26.

40 Gonzales E, Gonzales-Cabrero J, Egido J: Defective hepatic handling of IgA immune aggregates by mice with experimental IgA nephropathy. Immunology 1989;67:303-313.

41 Sato M, Ideura T, Koshikawa S: Experimental IgA nephropathy in mice. Lab Invest 1986;54: 377-384.

42 Isaacs KL, Miller F: Role of antigen size and charge in immune complex glomerulonephritis. I. Active induction of disease with dextran and its derivates. Lab Invest 1982;47:198205. 
43 Isaacs KL, Miller F: Antigen size and charge in immune complex glomerulonephritis. II. Passive induction of immune deposits with dextran-anti-dextran immune complexes. Am J Pathol 1983;111:298-306.

44 Montinaro V, Aventaggiato L, Cavallo T, Rifai A: Evolution of renal injury in a chronic model of IgA immune-complex-associated nephropathy. Nephrol Dial Transplant 1995;10:20352042.

45 Feehally J, Allen AC: Structural features of IgA molecules which contribute to IgA nephropathy. J Nephrol 1999;12:59-65.

46 Assmann KJ, Tangelder MM, Lange WP, Schrijver G, Koene RA: Anti-GBM nephritis in the mouse: Severe proteinuria in the heterologous phase. Virchows Arch A Pathol Anat Histopathol 1985;406:285-299.

47 Wilson CB: Immune models of glomerular injury; in Neilson EG, Couser WC (eds): Immunologic Renal Diseases. New York, LippincottRaven, 1997, pp 729-774.

48 Schrijver G, Bogman MJ, Assmann KJ, de Waal RM, Robben HJ, van Gasteren H, Koene RA: Anti-GBM nephritis in the mouse: Role of granulocytes in the heterologous phase. Kidney Int 1990;38:86-95.

49 Bolton WK, Benton FR, Sturgill BC: Autoimmune glomerulotubular nephropathy in mice. Clin Exp Immunol 1978;33:463-473.

50 Tipping PG, Huang XR, Berndt MC, Holdsworth SR: A role for P-selectin in complementindependent neutrophil-mediated glomerular injury. Kidney Int 1994;46:79-88.

51 Huang XR, Tipping PG, Shuo Li, Holdsworth $\mathrm{S}$ : Th1 responsiveness to nephritogenic antigens determines susceptibility to crescentic glomerulonephritis in mice. Kidney Int 1997;51: 94-103.

52 Huang XR, Holdsworth SR, Tipping PG: Th-2 responses induce humorally mediated injury in experimental anti-glomerular basement membrane glomerulonephritis. J Am Soc Nephrol 1997;8:1101-1108

53 Kitching AR, Holdsworth SR, Tipping PG IFN-gamma mediates crescent formation and cell-mediated immune injury in murine glomerulonephritis. J Am Soc Nephrol 1999;10: 752-759.

54 Kitching AR, Tipping PG, Mutch DA, Huang XR, Holdsworth SR: Interleukin-4 deficiency enhances Th1 responses and crescentic glomerulonephritis in mice. Kidney Int 1998;53:112118.

55 Janssen U, Ostendorf T, Gaertner S, Eitner F, Hedrich HJ, Assmann KJ, Floege J: Improved survival and amelioration of nephrotoxic nephritis in intercellular adhesion molecule-1 knockout mice. J Am Soc Nephrol 1998;9: 1805-1814.

56 Sheerin NS, Springall T, Carroll MC, Hartley $\mathrm{B}$, Sacks SH: Protection against anti-glomerular basement membrane (GBM)-mediated nephritis in C3- and C4-deficient mice. Clin Exp Immunol 1997;110:403-409.
57 Tesch GH, Schwarting A, Kinoshita K, Lan HY, Rollins BJ, Kelley VR: Monocyte chemoattractant protein-1 promotes macrophagemediated tubular injury, but not glomerular injury, in nephrotoxic serum nephritis. J Clin Invest 1999; 103:73-80.

58 Cattell V, Cook HT, Ebrahim H, Waddington SN, Wei XQ, Assmann KJ, Liew FY: AntiGBM glomerulonephritis in mice lacking nitric oxide synthase type 2. Kidney Int 1998;53: 932-936.

59 Li S, Holdsworth SR, Tipping PG: Antibody independent crescentic glomerulonephritis in mu chain deficient mice. Kidney Int 1997;51: 672-678.

60 Li S, Kurts C, Kontgen F, Holdsworth SR, Tipping PG: Major histocompatibility complex class II expression by intrinsic renal cells is required for crescentic glomerulonephritis. J Exp Med 1998;188:597-602.

61 Hisada Y, Sugaya T, Yamanouchi M, Uchida H, Fujimura H, Sakurai H, Fukamizu A, Marakami K: Angiotensin II plays a pathogenic role in immune-mediated renal injury in mice. $\mathrm{J}$ Clin Invest 1999;103:627-635.

62 Ryffel B, Eugster H, Haas C, Le Hir M: Failure to induce anti-glomerular basement membrane glomerulonephritis in TNF alpha/beta deficient mice. Int J Exp Pathol 1998;79:453-460.

63 Tipping PG, Huang XR, Qi M, Van GY, Tang WW: Crescentic glomerulonephritis in CD4and CD8-deficient mice: Requirement for CD4 but not CD8 cells. Am J Pathol 1998;152 1541-1548.

64 Eitner F, Westerhuis R, Burg M, Weinhold B, Grone HJ, Ostendorf T, Ruther U, Koch KM, Rees AJ, Floege J: Role of interleukin-6 in mediating mesangial cell proliferation and matrix production in vivo. Kidney Int 1997;51: 69-78.

65 Cattell V, Bradfield JW: Focal mesangial proliferative glomerulonephritis in the rat caused by Habu snake venom: A morphologic study. Am J Pathol 1977;87:511-524.

66 Cattell V, Mehotra A: Focal mesangial proliferative glomerulonephritis in the rat caused by Habu venom: The effect of antiplatelet agents. Br J Exp Pathol 1980;61:310-314.

67 Nakao H, Hiraiwa N, Yoshiki A, Ike F, Kusakabe M: Tenascin-C promotes healing of Habu-snake venom-induced glomerulonephritis: Studies in knockout congenic mice and in culture. Am J Pathol 1998;152:1237-1245.

68 Kashgarian M: Lupus nephritis: Lessons from the path lab. Kidney Int 1994;45:928-938.

69 Theofilopoulos AN, Dixon FJ: Etiopathogenesis of murine SLE. Immunol Rev 1991;55:179216.

70 Diaz Gallo C, Jevnikar AM, Brennan DC, Florquin S, Pacheco-Silva A, Kelley VR: Autoreactive kidney-infiltrating T-cell clones in murine lupus nephritis. Kidney Int 1992;42:851-859.

71 Mohan C, Datta SK: Lupus: Key pathogenic mechanisms and contributing factors. Clin Immunol Immunopathol 1995; 77:209-220.

72 Wakeland EK, Morel L, Mohan C, Yui M: Genetic dissection of lupus nephritis in murine models of SLE. J Clin Immunol 1997;17:272281 .
73 Clynes R, Dumitru C, Ravetch JV: Uncoupling of immune complex formation and kidney damage in autoimmune glomerulonephritis. Science 1998;279:1052-1054.

74 Haas C, Ryffel B, Le Hir M: IFN-gamma receptor deletion prevents autoantibody production and glomerulonephritis in lupus-prone (NZB $\times$ NZW)F1 mice. J Immunol 1998;160:37133718.

75 Schwarting A, Wada T, Kinoshita K, Tesch G, Kelley VR: IFN-gamma receptor signaling is essential for the initiation, acceleration, and destruction of autoimmune kidney disease in MRL-Fas(lpr) mice. J Immunol 1998;161:494503

76 Lloyd CM, Gonzalo JA, Salant DJ, Just J, Gutierrez-Ramos JC: Intercellular adhesion molecule-1 deficiency prolongs survival and protects against the development of pulmonary inflammation during murine lupus. J Clin Invest 1997;100:963-971.

77 Baldwin DS: Chronic glomerulonephritis: Nonimmunologic mechanisms of progressive glomerular damage. Kidney Int 1982;21:109120

78 Neuringer JR, Brenner BM: Hemodynamic theory of progressive renal disease: A 10-year update in brief review. Am J Kidney Dis 1992; 22:98-104.

79 Striker GE, He CJ, Liu RH, Yang DCW, Zalups RK, Esposito C, Striker LJ: Pathogenesis of nonimmune glomerulosclerosis: Studies in animals and potential applications to humans. Lab Invest 1995;73:596-605.

80 Kriz W, Elger M, Nagata M, Kretzler M, Uiker S, Koeppen-Hageman I, Tenschert S, Lemley $\mathrm{KV}$ : The role of podocytes in the development of glomerular sclerosis. Kidney Int 1994; 45(suppl):64-72.

81 Doi T, Striker LJ, Gibson CC, Agodoa LY, Brinster RL, Striker GE: Glomerular lesions in mice transgenic for growth hormone and insulinlike growth factor-I. I. Relationship between increased glomerular size and mesangial sclerosis. Am J Pathol 1990;137:541-552.

82 Doi T, Striker LJ, Kimata K, Peten EP, Yamada Y, Striker GE: Glomerulosclerosis in mice transgenic for growth hormone: Increased mesangial extracellular matrix is correlated with kidney mRNA levels. J Exp Med 1991; 173:1287-1290.

83 Wanke R, Hermanns W, Folger S, Wolf E, Brem G: Accelerated growth and visceral lesions in transgenic mice expressing foreign genes of the growth hormone family: An overview. Pediatr Nephrol 1991;5:513-521.

84 Brem G, Wanke R, Wolf E, Buchmüller T, Müller M, Brenig B, Hermanns W: Multiple consequences of human growth hormone expression in transgenic mice. Mol Biol Med 1989;6:531-547.

85 Weiher H, Noda T, Gray DA, Sharpe AH, Jaenisch R: Transgenic mouse model of kidney disease: Insertional inactivation of ubiquitously expressed gene leads to nephrotic syndrome. Cell 1990;62:425-434. 
86 MacKay K, Striker LJ, Pinkert CA, Brinster RL, Striker GE: Glomerulosclerosis and renal cysts in mice transgenic for the early region of SV40. Kidney Int 1987;32:827-837.

87 Kollias G, Evans DJ, Ritter M, Beech J, Morris R, Grosveld F: Ectopic expression of Thy1 in the kidneys of transgenic mice induces functional and proliferative abnormalities. Cell 1987;51:21-31.

88 Zalups RK: The Os/+ mouse: A genetic animal model of reduced renal mass. Am J Physiol 1993;264:F53-F60.

89 He C, Esposito C, Phillips C, Zalups RK, Henderson DA, Striker GE, Striker LJ: Dissociation of glomerular hypertrophy, cell proliferation, and glomerulosclerosis in mouse strains heterozygous for a mutation (Os) which induces a $50 \%$ reduction in nephron number. J Clin Invest 1996;97:1242-1249.

90 Lenz O, Zheng F, Vilar J, Doublier S, Lupia E, Schwedler S, Striker LJ, Striker GE: The inheritance of glomerulosclerosis in mice is controlled by multiple quantitative loci. Nephrol Dial Transplant 1998;13:30743078.

91 Remuzzi G, Bertani T: Pathophysiology of progressive nephropathies. N Engl J Med 1998;339:1448-1456.

92 Bruijn JA, Hogendorn PCW, Corver WE, van Elven EH, Hodemaker PJ, Fleuren GJ: Renal pathology and characterization of glomerular sclerosis in murine chronic graft-versus-host disease. Nephrol Dial Transplant 1987;2: 422-427.

93 Han JS, Doi K: Morphometric study on the renal glomeruli of streptozotocin (SZ)-induced diabetic APA hamsters. Histol Histopathol 1992;7:549-554.

94 Honoi K, Doi K, Mitsuoka T: Histopathology of streptozotocin-induced diabetic DBA/2N and CD-1 mice. Lab Anim 1986;20:298303.

95 Steffens MW, Maurer SM: Diabetic glomerulopathy in man and experimental models. Int Rev Exp Pathol 1984;26:147-175

96 Kume E, Doi C, Itagaki SI, Nagashima Y, Doi $\mathrm{K}$ : Glomerular lesions in unilateral nephrectomized and diabetic (UN-D) mice. $\mathrm{J}$ Vet Med Sci 1992;54:1085-1090.

97 Velasquez MT, Kimmel PL, Michaelis OE: Animal models of spontaneous diabetic kidney disease. FASEB J 1990;4:2850-2859.

98 Doi T, Hattori M, Agodoa LY, Sato T, Yoshida H, Striker LJ, Striker GE: Glomerular lesions in nonobese diabetic mouse: Before and after the onset of hyperglycemia. Lab Invest 1990;63:204-212.

99 Yang CW, Hattori M, Vlassara H, He CJ, Carome MA, Yamato E, Elliot S, Striker GE, Striker LJ: Overexpression of transforming growth factor-beta $1 \mathrm{mRNA}$ in associated with up-regulation of glomerular tenascin and laminin gene expression in nonobese diabetic mice. J Am Soc Nephrol 1995;5:1610-1617.

100 Gartner K: Glomerular hyperfiltration during the onset of diabetes mellitus in two strains of diabetic mice (C57BL/6J db/db and C57BL/ $\mathrm{KsJ} \mathrm{db} / \mathrm{db})$. Diabetologia 1978;15:59-63.
101 Cohen MP, Clements RS, Hud E, Cohen JA, Ziyadeh FN: Evolution of renal function abnormalities in the $\mathrm{db} / \mathrm{db}$ mouse that parallels the development of human diabetic nephropathy. Exp Nephrol 1996;4:166-171.

102 Lubec B, Rokitansky A, Hayde M, Aufricht $\mathrm{C}$, Wagner U, Mallinger WR, Hoger $\mathrm{H}$, Lubec G: Thiaproline reduces glomerular basement membrane thickness and collagen accumulation in the $\mathrm{db} / \mathrm{db}$ mouse. Nephron 1994;66: 333-336.

103 Wehner H, Hohn D, Faix-Schade U, Huber $\mathrm{H}$, Walzer P: Glomerular changes in mice with spontaneous hereditary diabetes. Lab Invest 1972;27:331-340.

104 Melez KA, Harrison LC, Gilliam JN, Steinberg AD: Diabetes is associated with autoimmunity in the New Zealand obese (NZO) mouse. Diabetes 1980;29:835-840.

105 Sumida T, Furukawa M, Sakamoto A, et al: Prevention of insulitis and diabetes in beta2-microglobulin-deficient non-obese diabetic mice. Int Immunol 1994;6:1445-1449.

106 Kelly CJ, Neilson EG: Tubulointerstitial disease; in Brenner BM (ed): The Kidney. Philadelphia, Saunders, 1996, pp 1655-1680.

107 Wilson CB: Immune models of tubulointerstitial injury; in Neilson EG, Couser WC (eds): Immunologic Renal Diseases. New York, Lippincott-Raven, 1997, pp 775-804.

108 Neilson EG, McCafferty E, Feldman A, Clayman MD, Zakheim B, Korngold R: Spontaneous interstitial nephritis in kdkd mice. I. An experimental model of autoimmune renal disease. J Immunol 1984;133:2560-2565.

109 Kelly CJ, Korngold R, Mann R, Clayman M, Haverty T, Neilson EG: Spontaneous interstitial nephritis in kdkd mice. II. Characterization of a tubular antigen-specific, H-2K-restricted Lyt-2+ effector $\mathrm{T}$ cell that mediates destructive tubulointerstitial injury. J Immunol 1986;136:526-531.

110 Rudofsky UH, Dilwith RL, Tung KSK: Susceptibility differences in inbred mice to induction of autoimmune renal tubulointerstitial lesions. Lab Invest 1980;43:463-470.

111 Neilson EG, McCafferty E, Mann R, Michaud L, Clayman M: Murine interstitial nephritis. III. The selection of phenotypic (Lyt and L3T4) and idiotypic (RE-Id) T cell preferences by genes in IgH-1 and $\mathrm{H}-2 \mathrm{~K}$ characterizes the cell-mediated potential for disease expression: Susceptible mice provide a unique effector $\mathrm{T}$ cell repertoire in response to tubular antigen. J Immunol 1985;134: 2375-2382.

112 Rubin-Kelley VE, Jevnikar AM: Antigen presentation by renal tubular epithelial cells. J Am Soc Nephrol 1991;2:13-16.

113 Zagheim B, McCafferty E, Phillips SM, Clayman M, Neilson EG: Murine interstitial nephritis. II. The adoptive transfer of disease with immune $\mathrm{T}$ lymphocytes produces a phenotypically complex interstitial lesion. J Immunol 1984;133:234-239.

114 Harris KPG, Klahr S, Schreiner G: Obstructive nephropathy: From mechanical disturbance to immune activation? Exp Nephrol 1993;1:198-204.
115 Steinhardt GF, Ramon G, Salinas-Madrigal L: Glomerulosclerosis in obstructive uropathy. J Urol 1988;140:1316-1318.

116 Fern RJ, Yesko CM, Thornhill BA, Kim HS, Smithies O, Chevalier RL: Reduced angiotensinogen expression attenuates renal interstitial fibrosis in obstructive nephropathy in mice. J Clin Invest 1999;103:39-46.

117 Lee BJ, Boring L, Hwang O, Tomaszewski JE, Charo I, Danoff TM: Obstructive nephropathy in CCR2-deficient mice (abstract). J Am Soc Nephrol 1998;9:2455.

118 Miao J, Roberts ISD, Schiffer M, Bottinger EP: Unilateral ureter obstruction (UUO) in mice with deletion of one allele of TGF-beta (abstract 2184). J Am Soc Nephrol 1998;9: 427.

119 Yamasaki Y, Danoff T, Iwano M, Takahashi K, Neilson E: B7 on tubular epithelial cells accelerate local inflammation and may trigger autoimmune reaction (abstract 2406). J Am Soc Nephrol 1998;9:470.

120 Ma J, Nishimura H, Fogo A, Kon V, Inagami T, Ichikawa I: Accelerated fibrosis and collagen deposition develop in the renal interstitium of angiotensin type 2 receptor null mutant mice during ureteral obstruction. Kidney Int 1998;53:937-944.

121 Thadhani R, Pascual M, Bonventre JV: Acute renal failure. N Engl J Med 1996;334:14481460.

122 Ling H, Edelstein C, Gengaro P, Meng X, Lucia S, Knotek M, Wangsiripaisan A, Shi Y, Schrier R: Attenuation of renal ischemiareperfusion injury in inducible nitric oxide synthase knockout mice. Am J Physiol 1999; 277:F383-F390.

123 Nogae S, Miyazaki M, Kobayashi N, Saito T, Abe K, Saito H, Nakane PK, Nakanishi Y, Koji T: Induction of apoptosis in ischemiareperfusion model of mouse kidney: Possible involvement of Fas. J Am Soc Nephrol 1998; 9:620-631.

124 Ouellette AJ, Malt RA, Sukhatme VP, Bonventre JV: Expression of two 'immediate early' genes, Egr-1 and c-fos, in response to renal ischemia and during compensatory renal hypertrophy in mice. J Clin Invest 1990;85: 766-771.

125 Haq M, Norman J, Saba SR, Ramirez G, Rabb H: Role of Il-1 in renal ischemic reperfusion injury. J Am Soc Nephrol 1998;9:614619.

126 Kelly KJ, Williams WW, Colvin RB, Meehan SM, Springer TA, Gutierrez-Ramos JC, Bonventre JV: Intercellular adhesion molecule-1deficient mice are protected against ischemic renal injury. J Clin Invest 1996;97:10561063.

127 Rabb H, Ramirez G, Saba SR, Reynolds D, $\mathrm{Xu}$ J, Flavell R, Antonia S: Renal ischemicreperfusion injury in L-selectin-deficient mice. Am J Physiol 1996;271:F408-F413.

128 Zager RA, Conrad S, Lochhead K, Sweeney EA, Igarashi Y, Burkhart KM: Altered sphingomyelinase and ceramide expression in the setting of ischmic and nephrotoxic acute renal failure. Kidney Int 1998;53:573-582. 
129 Parchure M, Ambaye RY, Lalitha VS, Gokhale SV: Acute toxicity of folic acid in mice. Exprientia 1985;15:72-73.

130 Calvet JP, Chadwick LJ: Primary and secondary genetic responses after folic acid-induced acute renal injury in the mouse. J Am Soc Nephrol 1994;5:1324-1332.

131 Cowley BD, Chadwick LJ, Grantham JJ, Calvet JP: Sequential protooncogene expression in regenerating kidney following acute renal injury. J Biol Chem 1989;15:8389-8393.

132 Kujubu DA: Differences in 'primary response' gene expression in renal compensatory hypertrophy and hyperplasia. Am J Kidney Dis 1991;17:641-643.

133 Zager RA: Rhabdomyolysis and myohemoglobinuric acute renal failure. Kidney Int 1996;49:314-326.

134 Ponraj D, Gopalakrishnakone P: Establishment of an animal model for myoglobinuria by use of a myotoxin from Pseudechis australis (king brown snake) venom in mice. Lab Anim Sci 1996;46:393-398.

135 Ponraj D, Gopalakrishnakone P: Renal lesions in rhabdomyolysis caused by Pseudechis australis snake myotoxin. Kidney Int 1997; 51:1956-1969.

136 Hata A, Tsunoo H, Nakajima H, Sgintaku K, Kimura M: Acute cadmium intoxication in inbred mice: A study on strain differences. Chem Biol Interact 1980;32:29-39.
137 Dorian C, Gattone VH, Klassen CD: Discrepancy between the nephrotoxic potencies of cadmium-metallothionein and cadmium chloride and the renal concentration of cadmium in the proximal convoluted tubules. Toxicol Appl Pharmacol 1995;130:161-168.

138 Maitani T, Cuppage FE, Klaassen CD: Nephrotoxicity of intravenously injected cadmium-metallothionein: Critical concentration and tolerance. Fundam Appl Toxicol 1988;10:98-108

139 Diamond GL, Zalups RK: Understanding renal toxicity of heavy metal. Toxicol Pathol 1998;26:92-103.

140 Moszczynski P: Mercury compounds and the immune system: A review. Int J Occup Med Environ Health 1997;10:247-258.

141 Nielsen JB, Andersen HR, Andersen O, Starklint $\mathrm{H}$ : Dose and time relation in $\mathrm{Hg}$ $(++)$-induced tubular necrosis and regeneration. Environ Health Perspect 1994;102 (suppl 3):317-320.

142 Tanaka T, Naganuma A, Imura N: Role of gamma-glutamyltranspeptidase in renal uptake and toxicity of inorganic mercury in mice. Toxicology 1990;60:187-198
143 Gabizon D, Goren E, Shaked U, Averbukh Z, Rosenmann E, Modai D: Induction of chronic renal failure in the mouse: A new model. Nephron 1985;40:349-352.

144 Gibb IA, Hamilton DN: An experimental model of chronic renal failure in mice. Clin Immunol Immunopathol 1985;35:276-284.

145 Kren S, Hostetter TH: The course of the remnant kidney model in mice. Kidney Int 1999; 56:333-337.

146 Gagnon RF, Gallimore B: Characterization of chronic uremia. Urol Res 1988;16:119126.

147 Banchaabouchi MA, Marescau B, D’Hooge R, Van Marck E, Van Daele A, Levillain O, De Deyn PP: Biochemical and histopathological changes in nephrectomized mice. Metabolism 1998;47:355-361.

148 Gagnon RF, Ansari M: Development and progression of uremic changes in the mouse with surgically induced renal failure. Nephron 1990;54:70-76.

149 Gagnon RF, Gold J, Gerstein W: A mouse model of delayed-type hypersensitivity skin changes in chronic renal failure. Uremia Invest 1984;8:121-125.

150 Brox AG, Zhang F, Guyda H, Gagnon RF: Subtherapeutic erythropoietin and insulinlike growth factor-1 correct the anemia of chronic renal failure in the mouse. Kidney Int 1996;50:937-943. 